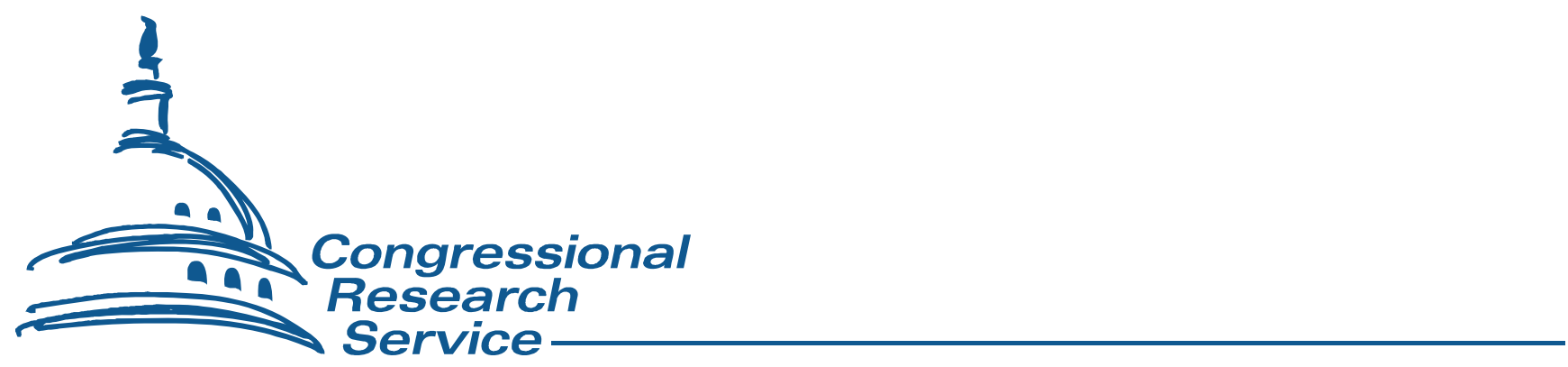

\title{
Carbon Capture and Sequestration (CCS)
}

\section{Peter Folger}

Specialist in Energy and Natural Resources Policy

February 23, 2009 


\section{Summary}

Carbon capture and sequestration (or storage) — known as CCS — has attracted interest as a measure for mitigating global climate change because potentially large amounts of carbon dioxide $\left(\mathrm{CO}_{2}\right)$ emitted from fossil fuel use in the United States could be captured and stored underground. Large, industrial sources of $\mathrm{CO}_{2}$, such as electricity-generating plants, are the most likely initial candidates for CCS because they are predominantly large, single-point sources. Electricitygenerating plants contribute approximately one-third of U.S. $\mathrm{CO}_{2}$ emissions from fossil fuels.

Congressional interest has grown markedly in CCS as part of a legislative strategy to address climate change. On February 13, 2009, Congress passed the American Recovery and Reinvestment Act (ARRA, P.L. 111-5) of 2009, which included \$3.4 billion for projects and programs related to CCS. Of that amount, $\$ 1.52$ billion would be made available for a competitive solicitation for industrial carbon capture and energy efficiency improvement projects, $\$ 1$ billion for fossil energy research and development, and $\$ 800$ million for U.S. Department of Energy Clean Coal Power Initiative Round III solicitations, which specifically target coal-based systems that capture and sequester, or reuse, $\mathrm{CO}_{2}$ emissions. The $\$ 3.4$ billion contained in ARRA greatly exceeds the federal government's cumulative outlays for CCS research and development since 1997.

The large and rapid influx of funding for industrial-scale CCS projects may accelerate development and deployment of $\mathrm{CO}_{2}$ capture technologies. Currently, large U.S. power plants do not capture large volumes of $\mathrm{CO}_{2}$ for CCS, even though technology is available that can potentially remove $80 \%-95 \%$ of $\mathrm{CO}_{2}$ from a point source. This is due to the absence of either an economic incentive (i.e., a price for captured $\mathrm{CO}_{2}$ ) or a regulatory requirement to curtail $\mathrm{CO}_{2}$ emissions. In addition, DOE estimates that CCS costs between $\$ 100$ and $\$ 300$ per metric ton (2,200 pounds) of carbon emissions avoided using current technologies. Those additional costs mean that power plants with CCS would require more fuel, and costs per kilowatt-hour would be higher than for plants without CCS.

After $\mathrm{CO}_{2}$ is captured from the source and compressed into a liquid, pipelines or ships would likely convey the captured $\mathrm{CO}_{2}$ to storage sites to be injected underground. Three main types of geological formations are being considered for storing large amounts of $\mathrm{CO}_{2}$ as a liquid: oil and gas reservoirs, deep saline reservoirs, and unmineable coal seams. The deep ocean also has a huge potential to store carbon; however, direct injection of $\mathrm{CO}_{2}$ into the deep ocean is still experimental, and environmental concerns have forestalled planned experiments in the open ocean. Mineral carbonation-reacting minerals with a stream of concentrated $\mathrm{CO}_{2}$ to form a solid carbonate-is well understood, but it is still an experimental process for storing large quantities of $\mathrm{CO}_{2}$.

The increase in funding for CCS provided for in ARRA may lead to less expensive and better technologies for capturing large quantities of $\mathrm{CO}_{2}$. Without a carbon price or a regulatory requirement to cap $\mathrm{CO}_{2}$ emissions, however, it will be difficult to predict or evaluate how the technology would be deployed throughout the U.S. energy sector. By comparison, transporting, injecting, and storing $\mathrm{CO}_{2}$ underground may be less daunting. A large pipeline infrastructure for transporting $\mathrm{CO}_{2}$ could be very costly, however, and considerable uncertainty remains over how large quantities of injected $\mathrm{CO}_{2}$ would be permanently stored underground. To help resolve these uncertainties, DOE has initiated seven large-scale $\mathrm{CO}_{2}$ injection tests in a variety of geologic reservoirs that are to take place over the next several years. 


\section{Contents}

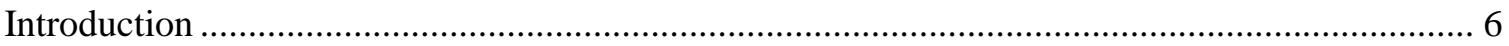

The American Recovery and Reinvestment Act (ARRA) of 2009 …........................................ 7

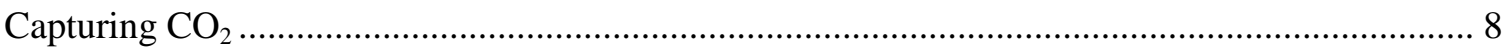

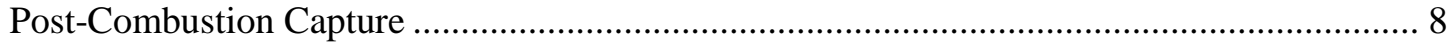

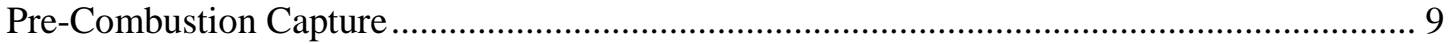

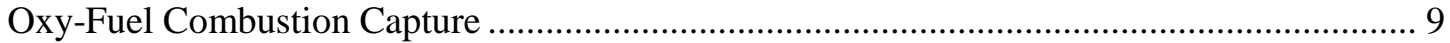

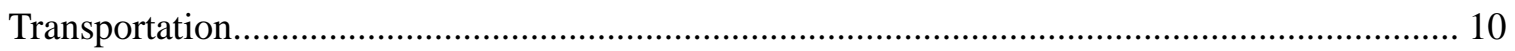

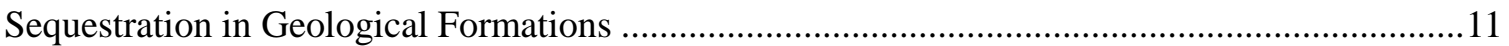

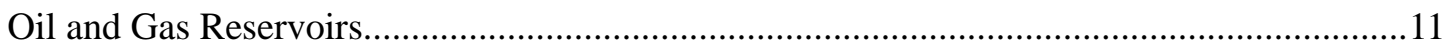

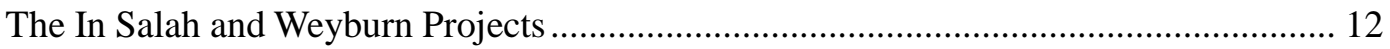

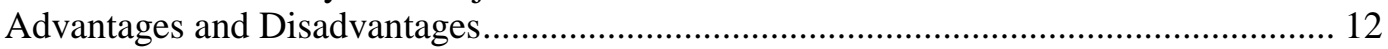

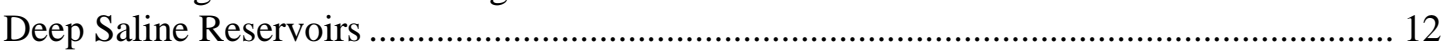

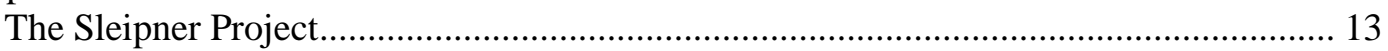

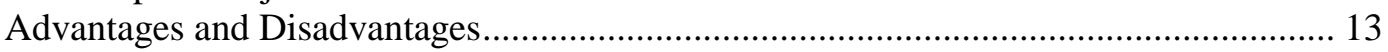

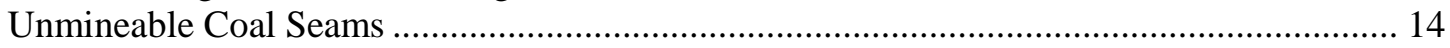

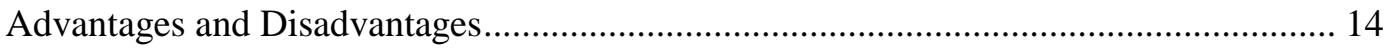

Geological Storage Capacity for $\mathrm{CO}_{2}$ in the United States .................................................... 15

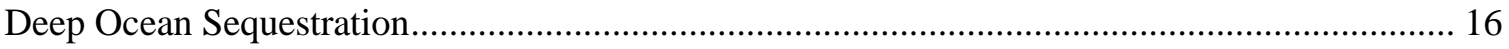

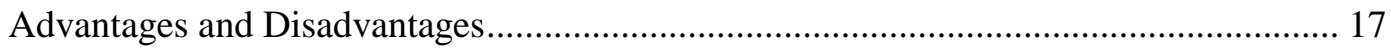

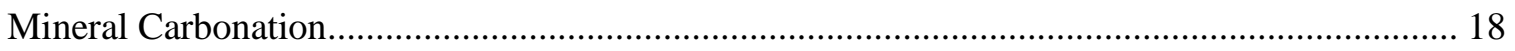

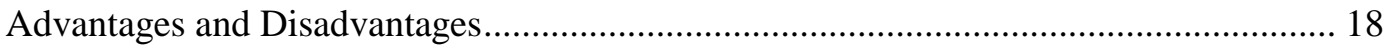

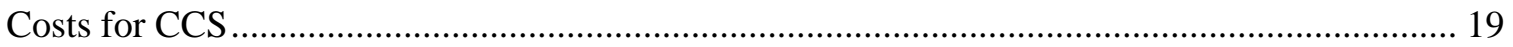

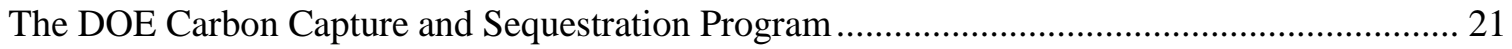

DOE CCS Research and Development Funding Through FY2008 …................................. 22

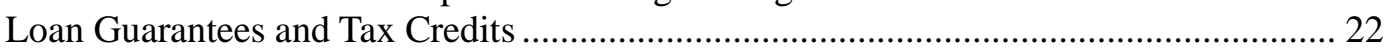

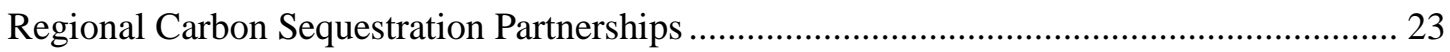

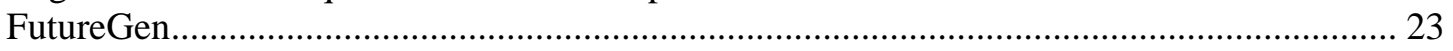

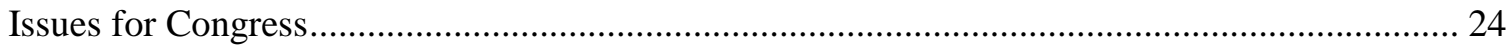

\section{Figures}

Figure 1. Simplified Illustration of Post-Combustion $\mathrm{CO}_{2}$ Capture .............................................. 8

Figure 2. Simplified Illustration of Pre-Combustion $\mathrm{CO}_{2}$ Capture ............................................... 9

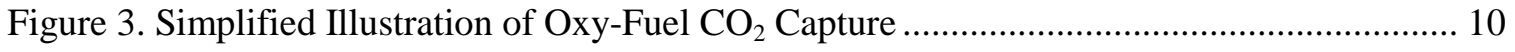

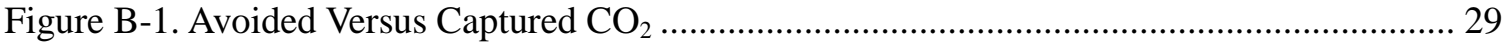

\section{Tables}

Table 1. Sources for $\mathrm{CO}_{2}$ Emissions in the United States from Combustion of Fossil

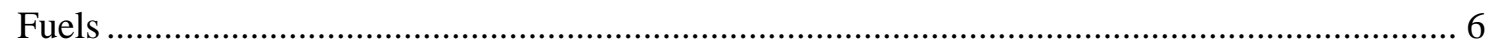


Table 2. Geological Sequestration Potential for the United States and Parts of Canada .............. 16

Table 3. Estimates of Additional Costs of Selected Carbon Capture Technology .......................... 20

Table 4. Estimates of CCS Costs at Different Stages of Development ........................................ 20

\section{Appendixes}

Appendix A. Carbon Sequestration Legislation in the $110^{\text {th }}$ Congress......................................... 27

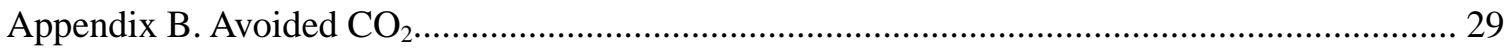

\section{Contacts}

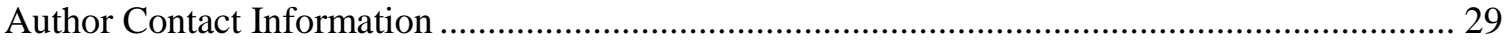




\section{Introduction}

Carbon capture and sequestration (or storage) — known as CCS—is capturing carbon at its source and storing it before its release to the atmosphere. CCS would reduce the amount of carbon dioxide $\left(\mathrm{CO}_{2}\right)$ emitted to the atmosphere despite the continued use of fossil fuels. An integrated CCS system would include three main steps: (1) capturing and separating $\mathrm{CO}_{2}$; (2) compressing and transporting the captured $\mathrm{CO}_{2}$ to the sequestration site; and (3) sequestering $\mathrm{CO}_{2}$ in geological reservoirs or in the oceans. As a measure for mitigating global climate change, CCS has attracted congressional interest because several projects in the United States and abroadtypically associated with oil and gas production - are successfully capturing, injecting, and storing $\mathrm{CO}_{2}$ underground, albeit at relatively small scales. The oil and gas industry in the United States injects approximately 48 million metric tons of $\mathrm{CO}_{2}$ underground each year to help recover oil and gas resources (enhanced oil recovery, or EOR). ${ }^{1}$ Also, potentially large amounts of $\mathrm{CO}_{2}$ generated from fossil fuels - as much as one-third of the total $\mathrm{CO}_{2}$ emitted in the United States, over 2 billion metric tons per year-could be eligible for large-scale CCS. ${ }^{2}$

Fuel combustion accounts for $94 \%$ of all U.S. $\mathrm{CO}_{2}$ emissions. ${ }^{3}$ Electricity generation contributes the largest proportion of $\mathrm{CO}_{2}$ emissions compared to other types of fossil fuel use in the United States. (See Table 1.) Electricity-generating plants are among the most likely initial candidates for capture, separation, and storage, or reuse of $\mathrm{CO}_{2}$ because they are predominantly large, singlepoint sources for emissions. Large industrial facilities, such as cement-manufacturing, ethanol, or hydrogen production plants, that produce large quantities of $\mathrm{CO}_{2}$ as part of the industrial process are also good candidates for $\mathrm{CO}_{2}$ capture and storage. ${ }^{4}$

Table I. Sources for $\mathrm{CO}_{2}$ Emissions in the United States from Combustion of Fossil Fuels

\begin{tabular}{lcc}
\hline Sources & CO $_{2}$ Emissions & Percent $^{\mathbf{a}}$ \\
\hline Electricity generation & $\mathbf{b}$ \\
Transportation & $2,273.3$ & $41 \%$ \\
Industrial & $1,856.0$ & $33 \%$ \\
Residential & 862.2 & $15 \%$ \\
Commercial & 326.5 & $6 \%$ \\
Total & 210.1 & $4 \%$ \\
\hline
\end{tabular}

Source: U.S. Environmental Protection Agency (EPA), Inventory of U.S. Greenhouse Emissions and Sinks: 19902006, Table ES-3; see http://epa.gov/climatechange/emissions/usinventoryreport.html.

a. $\mathrm{CO}_{2}$ emissions in millions of metric tons for 2006; excludes emissions from U.S. territories.

\footnotetext{
${ }^{1}$ U.S. DOE, Carbon Sequestration Through Enhanced Oil Recovery, National Energy Technology Laboratory (March, 2008), at http://www.netl.doe.gov/publications/factsheets/program/Prog053.pdf.

${ }^{2}$ DOE estimates that large, fossil-fuel power plants account for one-third of all U.S. $\mathrm{CO}_{2}$ emissions; see http://www.fossil.energy.gov/programs/sequestration/overview.html.

${ }^{3}$ U.S. Environmental Protection Agency (EPA), Inventory of U.S. Greenhouse Emissions and Sinks: 1990-2006, p. ES7. The percentage refers to U.S. emissions in 2006; see http://epa.gov/climatechange/emissions/usinventoryreport.html.

${ }^{4}$ Intergovernmental Panel on Climate Change (IPCC) Special Report: Carbon Dioxide Capture and Storage, 2005.

(Hereafter referred to as IPCC Special Report.)
} 
b. Total does not sum to $100 \%$ because of rounding.

Congressional interest in CCS, as part of legislation addressing climate change, is growing. In its first month, the $111^{\text {th }}$ Congress passed the American Recovery and Reinvestment Act (ARRA) of 2009, which included $\$ 3.4$ billion for CCS-related activities. In the $110^{\text {th }}$ Congress, several bills that would have established comprehensive cap-and-trade programs for limiting greenhouse gas emissions also included provisions for geologic sequestration. (See Appendix A for a discussion of legislation in the $110^{\text {th }}$ Congress.) Comprehensive cap-and-trade legislation in the $111^{\text {th }}$ Congress will likely also include provisions for CCS. At issue for Congress is whether the "technology-push" approach of investing in research and development, such as the large influx of funding provided in ARRA, will spur commercial deployment of CCS even without a market demand - created through a price mechanism or regulatory requirement. Even if CCS technology becomes more efficient and cheaper as a result of federal investment in $R \& D$, few companies may have the incentive to install such technology unless they are required to do so.

This report covers only CCS and not other types of carbon sequestration activities whereby $\mathrm{CO}_{2}$ is removed from the atmosphere and stored in vegetation, soils, or oceans. Forests and agricultural lands store carbon, and the world's oceans exchange huge amounts of $\mathrm{CO}_{2}$ from the atmosphere through natural processes. ${ }^{5}$

\section{The American Recovery and Reinvestment Act (ARRA) of 2009}

Funding for carbon capture and sequestration technology may increase substantially as a result of enactment of ARRA (P.L. 111-5). In the compromise legislation considered in conference on February 11, 2009, the conferees agreed to provide $\$ 3.4$ billion through FY2010 for fossil energy research and development. Of that amount, $\$ 1.52$ billion would be made available for a competitive solicitation for industrial carbon capture and energy efficiency improvement projects, according to the explanatory statement accompanying the legislation. This provision likely refers to a program for large scale demonstration projects that capture $\mathrm{CO}_{2}$ from a range of industrial sources. A small portion of the $\$ 1.52$ billion would be allocated for developing innovative concepts for reusing $\mathrm{CO}_{2}$, according to the explanatory statement. Of the remaining $\$ 1.88$ billion, $\$ 1$ billion would be available for fossil energy research and development programs. The explanatory statement does not specify which program or programs would receive funding, however, or how the $\$ 1$ billion would be allocated. Of the remaining $\$ 880$ million, the conferees agreed to allocate $\$ 800$ million to the DOE Clean Coal Power Initiative Round III solicitations, which specifically target coal-based systems that capture and sequester, or reuse, $\mathrm{CO}_{2}$ emissions. Lastly, \$50 million would be allocated for site characterization activities in geologic formations (for the storage component of CCS activities), \$20 million for geologic sequestration training and research, and $\$ 10$ million for unspecified program activities.

\footnotetext{
${ }^{5}$ For more information about carbon sequestration in forests and agricultural lands, see CRS Report RL31432, Carbon Sequestration in Forests, by Ross W. Gorte; CRS Report RL33898, Climate Change: The Role of the U.S. Agriculture Sector, by Renée Johnson, and CRS Report R40186, Biochar: Examination of an Emerging Concept to Mitigate Climate Change, by Kelsi S. Bracmort. For more information about carbon exchanges between the oceans, atmosphere, and land surface, see CRS Report RL34059, The Carbon Cycle: Implications for Climate Change and Congress, by Peter Folger.
} 
If the bulk of the $\$ 3.4$ billion agreed to by conferees for fossil energy research and development is used for CCS activities, it would represent a substantial infusion of funding compared to current spending levels. It would also be a large and rapid increase in funding over what DOE spent on CCS cumulatively over the 11 years between FY1997 through FY2007 (slightly less than $\$ 500$ million). Moreover, the bulk of DOE's CCS program would shift to the capture component of CCS, unless funding for the storage component increases commensurately in annual appropriations. The large and rapid increase in funding, compared to the magnitude and pace of previous CCS spending, may raise questions about how efficiently the new funding could be used to spur innovation for carbon capture technology.

\section{Capturing $\mathrm{CO}_{2}$}

The first step in CCS is to capture $\mathrm{CO}_{2}$ at the source and produce a concentrated stream for transport and storage. Currently, three main approaches are available to capture $\mathrm{CO}_{2}$ from largescale industrial facilities or power plants: (1) post-combustion capture, (2) pre-combustion capture, and (3) oxy-fuel combustion capture. For power plants, current commercial $\mathrm{CO}_{2}$ capture systems could operate at $85 \%-95 \%$ capture efficiency. ${ }^{6}$ Techniques for capturing $\mathrm{CO}_{2}$ have not yet been applied to large power plants (e.g., 500 megawatts or more). ${ }^{7}$

\section{Post-Combustion Capture}

This process involves extracting $\mathrm{CO}_{2}$ from the flue gas following combustion of fossil fuels or biomass. Several commercially available technologies, some involving absorption using chemical solvents, can in principle be used to capture large quantities of $\mathrm{CO}_{2}$ from flue gases. U.S. commercial electricity-generating plants currently do not capture large volumes of $\mathrm{CO}_{2}$ because they are not required to and there are no economic incentives to do so. Nevertheless, the postcombustion capture process includes proven technologies that are commercially available today. Figure 1 shows a simplified illustration of this process.

Figure I. Simplified Illustration of Post-Combustion $\mathrm{CO}_{2}$ Capture

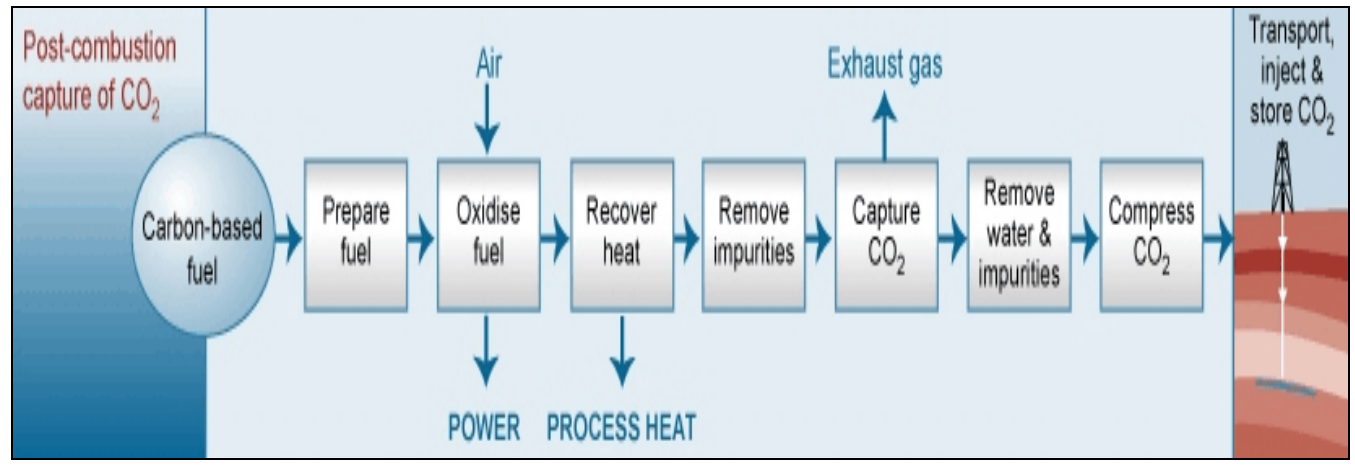

Source: Scottish Centre for Carbon Storage. Figure available at http://www.geos.ed.ac.uk/sccs/capture/ precombustion.html

${ }^{6}$ IPCC Special Report, p. 107.

${ }^{7}$ Ibid., p. 25. 


\section{Pre-Combustion Capture}

This process separates $\mathrm{CO}_{2}$ from the fuel by combining it with air and/or steam to produce hydrogen for combustion and a separate $\mathrm{CO}_{2}$ stream that could be stored. The most common technologies today use steam reforming, in which steam is employed to extract hydrogen from natural gas. ${ }^{8}$ In the absence of a requirement or economic incentives, pre-combustion technologies have not been used for power systems, such as natural gas combined-cycle power plants. Figure 2 shows a simplified illustration of this process.

Pre-combustion capture of $\mathrm{CO}_{2}$ is viewed by some as a necessary requirement for coal-to-liquid fuel processes, whereby coal can be converted through a catalyzed chemical reaction to a variety of liquid hydrocarbons. Concerns have been raised because the coal-to-liquid process releases $\mathrm{CO}_{2}$, and the end product-the liquid fuel itself-further releases $\mathrm{CO}_{2}$ when combusted. Precombustion capture during the coal-to-liquid process would reduce the total amount of $\mathrm{CO}_{2}$ emitted, although $\mathrm{CO}_{2}$ would still be released during combustion of the liquid fuel used for transportation or electricity generation. ${ }^{9}$

Figure 2. Simplified Illustration of Pre-Combustion $\mathrm{CO}_{2}$ Capture

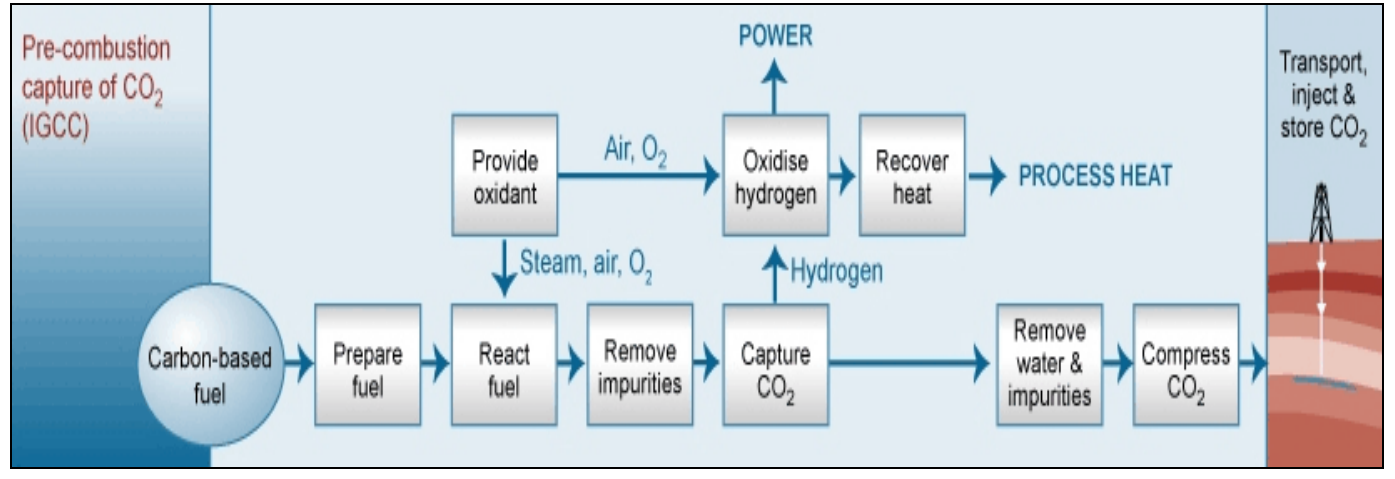

Source: Scottish Centre for Carbon Storage. Figure available at http://www.geos.ed.ac.uk/sccs/capture/ precombustion.html.

\section{Oxy-Fuel Combustion Capture}

This process uses oxygen instead of air for combustion and produces a flue gas that is mostly $\mathrm{CO}_{2}$ and water, which are easily separable, after which the $\mathrm{CO}_{2}$ can be compressed, transported, and stored. This technique is still considered developmental, in part because temperatures of pure oxygen combustion (about $3,500^{\circ}$ Celsius) are far too high for typical power plant materials..$^{10}$ Figure 3 shows a simplified illustration of this process.

\footnotetext{
${ }^{8}$ IPCC Special Report, p. 130.

${ }^{9}$ For more information on the coal-to-liquid process and issues for Congress, see CRS Report RL34133, FischerTropsch Fuels from Coal, Natural Gas, and Biomass: Background and Policy, by Anthony Andrews and Jeffrey Logan.

${ }^{10}$ IPCC Special Report, p. 122.
} 
Figure 3. Simplified Illustration of Oxy-Fuel $\mathrm{CO}_{2}$ Capture

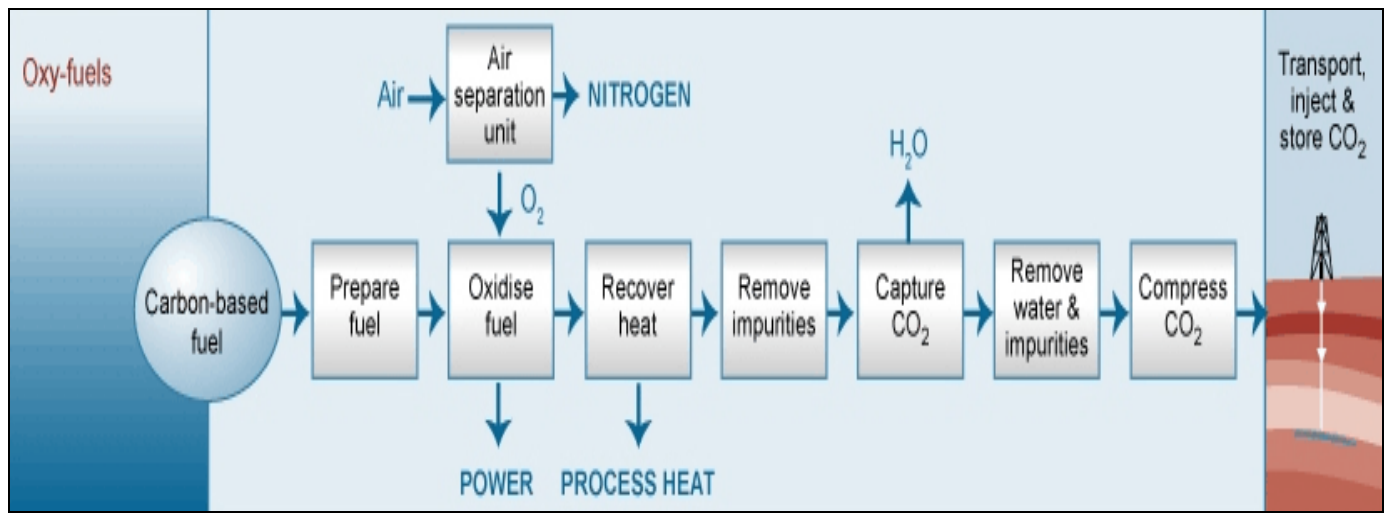

Source: Scottish Centre for Carbon Storage. Figure available at http://www.geos.ed.ac.uk/sccs/capture/ oxyfuel.html.

Application of these technologies to power plants generating several hundred megawatts of electricity has not yet been demonstrated. ${ }^{11}$ Also, up to $80 \%$ of the total costs for CCS may be associated with the capture phase of the CCS process. ${ }^{12}$

\section{Transportation}

Pipelines are the most common method for transporting $\mathrm{CO}_{2}$ in the United States. Currently, over 5,800 kilometers (about 3,600 miles) of pipeline transport $\mathrm{CO}_{2}$ in the United States, predominately to oil and gas fields, where it is used for enhanced oil recovery (EOR). ${ }^{13}$

Transporting $\mathrm{CO}_{2}$ in pipelines is similar to transporting petroleum products like natural gas and oil; it requires attention to design, monitoring for leaks, and protection against overpressure, especially in populated areas. ${ }^{14}$

Using ships may be feasible when $\mathrm{CO}_{2}$ needs to be transported over large distances or overseas. Ships transport $\mathrm{CO}_{2}$ today, but at a small scale because of limited demand. Liquefied natural gas, propane, and butane are routinely shipped by marine tankers on a large scale worldwide. Rail cars and trucks can also transport $\mathrm{CO}_{2}$, but this mode would probably be uneconomical for large-scale CCS operations.

Costs for pipeline transport vary, depending on construction, operation and maintenance, and other factors, including right-of-way costs, regulatory fees, and more. The quantity and distance transported will mostly determine costs, which will also depend on whether the pipeline is onshore or offshore, the level of congestion along the route, and whether mountains, large rivers,

\footnotetext{
${ }^{11}$ The Schwarze-Pumpe $30 \mathrm{MW}$ oxy-fuel pilot plant in Germany has been operating since mid-2008. The captured $\mathrm{CO}_{2}$ will be used for enhanced gas recovery at a nearby natural gas field. See http://www.vattenfall.com/www/co2_en/ co2_en/Gemeinsame_Inhalte/DOCUMENT/388963co2x/401837co2x/P0277108.pdf.

${ }^{12}$ Steve Furnival, reservoir engineer at Senergy, Ltd., "Burying Climate Change for Good," Physics World; see http://physicsweb.org/articles/world/19/9/3/1.

${ }^{13}$ U.S. Department of Transportation, National Pipeline Mapping System database (June 2005), at https://www.npms.phmsa.dot.gov/. By comparison, nearly 800,000 kilometers (500,000 miles) of pipeline operates to convey natural gas and hazardous liquids in the United States.

${ }^{14}$ IPCC Special Report, p. 181.
} 
or frozen ground are encountered. Shipping costs are unknown in any detail, however, because no large-scale $\mathrm{CO}_{2}$ transport system (in millions of metric tons of $\mathrm{CO}_{2}$ per year, for example) is operating. Ship costs might be lower than pipeline transport for distances greater than 1,000 kilometers and for less than a few million metric tons of $\mathrm{CO}_{2}\left(\mathrm{MtCO}_{2}\right)^{15}$ transported per year. ${ }^{16}$

Even though regional $\mathrm{CO}_{2}$ pipeline networks currently operate in the United States for enhanced oil recovery (EOR), developing a more expansive network for CCS could pose numerous regulatory and economic challenges. Some of these include questions about pipeline network requirements, economic regulation, utility cost recovery, regulatory classification of $\mathrm{CO}_{2}$ itself, and pipeline safety. ${ }^{17}$

\section{Sequestration in Geological Formations}

Three main types of geological formations are being considered for carbon sequestration: (1) depleted oil and gas reservoirs, (2) deep saline reservoirs, and (3) unmineable coal seams. In each case, $\mathrm{CO}_{2}$ would be injected, in a dense form, below ground into a porous rock formation that holds or previously held fluids. By injecting $\mathrm{CO}_{2}$ below 800 meters in a typical reservoir, the pressure induces $\mathrm{CO}_{2}$ to become supercritical—a relatively dense liquid—and thus less likely to migrate out of the geological formation. Injecting $\mathrm{CO}_{2}$ into deep geological formations uses existing technologies that have been primarily developed by and used for the oil and gas industry, and that could potentially be adapted for long-term storage and monitoring of $\mathrm{CO}_{2}$. Other underground injection applications in practice today, such as natural gas storage, deep injection of liquid wastes, and subsurface disposal of oil-field brines, can also provide information for sequestering $\mathrm{CO}_{2}$ in geological formations. ${ }^{18}$

The storage capacity for $\mathrm{CO}_{2}$ storage in geological formations is potentially huge if all the sedimentary basins in the world are considered. ${ }^{19}$ The suitability of any particular site, however, depends on many factors including proximity to $\mathrm{CO}_{2}$ sources and other reservoir-specific qualities like porosity, permeability, and potential for leakage.

\section{Oil and Gas Reservoirs}

Pumping $\mathrm{CO}_{2}$ into oil and gas reservoirs to boost production (enhanced oil recovery, or EOR) is practiced in the petroleum industry today. The United States is a world leader in this technology and injects approximately $48 \mathrm{MtCO}_{2}$ underground each year to help recover oil and gas resources. ${ }^{20}$ Carbon dioxide can be stored onshore or offshore; to date, most $\mathrm{CO}_{2}$ projects

\footnotetext{
${ }^{15}$ One metric ton of $\mathrm{CO}_{2}$ equivalent is written as $1 \mathrm{tCO}_{2}$; one million metric tons is written as $1 \mathrm{MtCO}_{2}$; one billion metric tons is written as $1 \mathrm{GtCO}_{2}$.

${ }^{16}$ IPCC Special Report, p. 31.

${ }^{17}$ These issues are discussed in more detail in CRS Report RL33971, Carbon Dioxide (CO2) Pipelines for Carbon Sequestration: Emerging Policy Issues, by Paul W. Parfomak and Peter Folger, and CRS Report RL34316, Pipelines for Carbon Dioxide (CO2) Control: Network Needs and Cost Uncertainties, by Paul W. Parfomak and Peter Folger.

${ }^{18}$ IPCC Special Report, p. 31.

${ }^{19}$ Sedimentary basins refer to natural large-scale depressions in the Earth's surface that are filled with sediments and fluids and are therefore potential reservoirs for $\mathrm{CO}_{2}$ storage.

${ }^{20}$ U.S. DOE, Carbon Sequestration Through Enhanced Oil Recovery, National Energy Technology Laboratory (March 2008), at http://www.netl.doe.gov/publications/factsheets/program/Prog053.pdf.
} 
associated with EOR are onshore, with the bulk of U.S. activities in west Texas. The advantage of using this technique for long-term $\mathrm{CO}_{2}$ storage is that sequestration costs can be partially offset by revenues from oil and gas production. Carbon dioxide can also be injected into oil and gas reservoirs that are completely depleted, which would serve the purpose of long-term sequestration, but without any offsetting benefit from oil and gas production.

\section{The In Salah and Weyburn Projects}

The In Salah Project in Algeria is the world's first large-scale effort to store $\mathrm{CO}_{2}$ in a natural gas reservoir. ${ }^{21}$ At In Salah, $\mathrm{CO}_{2}$ is separated from the produced natural gas and then reinjected into the same formation. Approximately $17 \mathrm{MtCO}_{2}$ are planned to be captured and stored over the lifetime of the project.

The Weyburn Project in south-central Canada uses $\mathrm{CO}_{2}$ produced from a coal gasification plant in North Dakota for EOR, injecting up to $5,000 \mathrm{tCO}_{2}$ per day into the formation and recovering oil. ${ }^{22}$ Approximately $20 \mathrm{MtCO}_{2}$ are expected to remain in the formation over the lifetime of the project.

\section{Advantages and Disadvantages}

Depleted or abandoned oil and gas fields, especially in the United States, are considered prime candidates for $\mathrm{CO}_{2}$ storage for several reasons:

- oil and gas originally trapped did not escape for millions of years, demonstrating the structural integrity of the reservoir;

- extensive studies have typically characterized the geology of the reservoir;

- computer models have often been developed to understand how hydrocarbons move in the reservoir, and the models could be applied to predicting how $\mathrm{CO}_{2}$ could move; and

- infrastructure and wells from oil and gas extraction may be in place and might be used for handling $\mathrm{CO}_{2}$ storage.

Some of these features could also be disadvantages to $\mathrm{CO}_{2}$ sequestration. Wells that penetrate from the surface to the reservoir could be conduits for $\mathrm{CO}_{2}$ release if they are not plugged properly. Care must be taken not to overpressure the reservoir during $\mathrm{CO}_{2}$ injection, which could fracture the caprock - the part of the formation that formed a seal to trap oil and gas-and subsequently allow $\mathrm{CO}_{2}$ to escape. Also, shallow oil and gas fields (those less than 800 meters deep, for example) may be unsuitable because $\mathrm{CO}_{2}$ may form a gas instead of a denser liquid and could escape to the surface more easily.

\section{Deep Saline Reservoirs}

Some rocks in sedimentary basins are saturated with brines or brackish water unsuitable for agriculture or drinking. As with oil and gas, deep saline reservoirs can be found onshore and

\footnotetext{
${ }^{21}$ IPCC Special Report, p. 203.
}

${ }^{22}$ Ibid., p. 204. 
offshore; in fact, they are often part of oil and gas reservoirs and share many characteristics. The oil industry routinely injects brines recovered during oil production into saline reservoirs for disposal. ${ }^{23}$ Using saline reservoirs for $\mathrm{CO}_{2}$ sequestration has several advantages: (1) they are more widespread in the United States than oil and gas reservoirs and thus have greater probability of being close to large point sources of $\mathrm{CO}_{2}$; and (2) saline reservoirs have potentially the largest reservoir capacity of the three types of geologic formations.

\section{The Sleipner Project}

The Sleipner Project in the North Sea is the first commercial-scale operation for sequestering $\mathrm{CO}_{2}$ in a deep saline reservoir. The Sleipner project has been operating since 1996, and it injects and stores approximately $2,800 \mathrm{tCO}_{2}$ per day, or about $1 \mathrm{MtCO} 2$ per year. ${ }^{24}$ Carbon dioxide is separated from natural gas production at the nearby Sleipner West Gas Field, compressed, and then injected 800 meters below the seabed of the North Sea into the Utsira formation, a sandstone reservoir 200-250 meters (650-820 feet) thick containing saline fluids. Monitoring has indicated the $\mathrm{CO}_{2}$ has not leaked from the saline reservoir, and computer simulations suggest that the $\mathrm{CO}_{2}$ will eventually dissolve into the saline water, reducing the potential for leakage in the future.

Large $\mathrm{CO}_{2}$ sequestration projects, similar to Sleipner, are being planned in western Australia (the Gorgon Project) ${ }^{25}$ and in the Barents Sea (the Snohvit Project), ${ }^{26}$ that would inject 10,000 and $2,000 \mathrm{tCO}_{2}$ per day respectively, when at full capacity. Similar to the Sleipner operation, both projects plan to strip $\mathrm{CO}_{2}$ from produced natural gas and inject it into deep saline formations for permanent storage.

\section{Advantages and Disadvantages}

Although deep saline reservoirs have huge potential capacity to store $\mathrm{CO}_{2}$, estimates of lower and upper capacities vary greatly, reflecting a high degree of uncertainty in how to measure storage capacity. ${ }^{27}$ Actual storage capacity may have to be determined on a case-by-case basis.

In addition, some studies have pointed out potential problems with maintaining the integrity of the reservoir because of chemical reactions following $\mathrm{CO}_{2}$ injection. Injecting $\mathrm{CO}_{2}$ can acidify (lower the $\mathrm{pH}$ of) the fluids in the reservoir, dissolving minerals such as calcium carbonate, and possibly increasing permeability. Increased permeability could allow $\mathrm{CO}_{2}$-rich fluids to escape the reservoir along new pathways and contaminate aquifers used for drinking water.

In an October 2004 experiment, researchers injected 1,600 tCO 1,500 meters deep into the Frio Formation-a saline reservoir containing oil and gas—along the Gulf Coast near Dayton, TX, to test its performance for $\mathrm{CO}_{2}$ sequestration and storage. ${ }^{28}$ Test results indicated that calcium

\footnotetext{
${ }^{23}$ DOE Office of Fossil Energy; see http://www.fossil.energy.gov/programs/sequestration/geologic/index.html.

${ }^{24}$ IEA Greenhouse Gas R\&D Programme, RD\&D Projects Database, at http://www.co2captureandstorage.info/project_specific.php?project_id=26.

${ }^{25} \mathrm{Ibid}$, at http://www.co2captureandstorage.info/project_specific.php?project_id=122.

${ }^{26} \mathrm{Ibid}$, at http://www.co2captureandstorage.info/project_specific.php?project_id=35.

${ }^{27}$ IPCC Special Report, p. 223.

${ }^{28}$ Y. K. Kharaka, et al., "Gas-water interactions in the Frio Formation following $\mathrm{CO}_{2}$ injection: implications for the storage of greenhouse gases in sedimentary basins," Geology, v. 34, no. 7 (July, 2006), pp. 577-580.
} 
carbonate and other minerals rapidly dissolved following injection of the $\mathrm{CO}_{2}$. The researchers also measured increased concentrations of iron and manganese in the reservoir fluids, suggesting that the dissolved minerals had high concentrations of those metals. The results raised the possibility that toxic metals and other compounds might be liberated if $\mathrm{CO}_{2}$ injection dissolved minerals that held high concentrations of those substances.

Another concern is whether the injected fluids, with $\mathrm{pH}$ lowered by $\mathrm{CO}_{2}$, would dissolve cement used to seal the injection wells that pierce the formation from the ground surface. Leaky injection wells could then also become pathways for $\mathrm{CO}_{2}$-rich fluids to migrate out of the saline formation and contaminate fresher groundwater above. Approximately six months after the injection experiment at the Dayton site, however, researchers did not detect any leakage upwards into the overlying formation, suggesting that the integrity of the saline reservoir formation remained intact at that time.

Preliminary results from a second injection test in the Frio Formation appear to replicate results from the first experiment, indicating that the integrity of the saline reservoir formation remained intact, and that the researchers could detect migration of the $\mathrm{CO}_{2}$-rich plume from the injection point to the observation well in the target zone. These results suggest to the researchers that they have the data and experimental tools to move to the next, larger-scale, phase of $\mathrm{CO}_{2}$ injection experiments. ${ }^{29}$

\section{Unmineable Coal Seams}

According to DOE, nearly $90 \%$ of U.S. coal resources are not mineable with current technology, because the coal beds are not thick enough, the beds are too deep, or the structural integrity of the coal bed ${ }^{30}$ is inadequate for mining. Even if they cannot be mined, coal beds are commonly permeable and can trap gases, such as methane, which can be extracted (a resource known as coal bed methane, or CBM). Methane and other gases are physically bound (adsorbed) to the coal. Studies indicate that $\mathrm{CO}_{2}$ binds even more tightly to coal than methane. ${ }^{31}$ Carbon dioxide injected into permeable coal seams could displace methane, which could be recovered by wells and brought to the surface, providing a source of revenue to offset the costs of $\mathrm{CO}_{2}$ injection.

\section{Advantages and Disadvantages}

Unmineable coal seam injection projects would need to assess several factors in addition to the potential for CBM extraction. These include depth, permeability, coal bed geometry (a few thick seams, not several thin seams), lateral continuity and vertical isolation (less potential for upward leakage), and other considerations. Once $\mathrm{CO}_{2}$ is injected into a coal seam, it would likely remain there unless the seam is depressurized or the coal is mined. Also, many unmineable coal seams in the United States are located near electricity-generating facilities, which could reduce the distance and cost of transporting $\mathrm{CO}_{2}$ from large point sources to storage sites.

\footnotetext{
${ }^{29}$ Personal communication with Susan D. Hovorka, principal investigator for the Frio Project, Bureau of Economic Geology, Jackson School of Geosciences, University of Texas at Austin, Aug. 22, 2007.

${ }^{30}$ Coal bed and coal seam are interchangeable terms.

${ }^{31}$ IPCC Special Report, p. 217.
} 
Not all types of coal beds are suitable for CBM extraction. Without the coal bed methane resource, the sequestration process would be less economically attractive. No commercial $\mathrm{CO}_{2}$ injection and sequestration project in coal beds is currently underway.

Without ongoing commercial experience, storing $\mathrm{CO}_{2}$ in coal seams has significant uncertainties compared to the other two types of geological storage discussed. According to IPCC, unmineable coal seams have the smallest potential capacity for storing $\mathrm{CO}_{2}$ globally compared to oil and gas fields or deep saline formations. DOE indicates that unmineable coal seams in the United States, however, have more potential capacity than oil and gas fields for storing $\mathrm{CO}_{2}$. The discrepancy could represent the relatively abundant U.S. coal reserves compared to other regions in the world, or it might also indicate the level of uncertainty in estimating the $\mathrm{CO}_{2}$ storage capacity in unmineable coal seams.

\section{Geological Storage Capacity for $\mathrm{CO}_{2}$ in the United States}

According to the DOE 2008 Carbon Sequestration Atlas, ${ }^{32}$ at least one of each of these three types of potential $\mathrm{CO}_{2}$ reservoirs occurs across most of the United States in relative proximity to many large point sources of $\mathrm{CO}_{2}$, such as fossil fuel power plants or cement plants. The 2008 Carbon Sequestration Atlas replaces the 2007 version, and contains a substantial expansion of the estimated storage capacity for oil and gas reservoirs and for deep saline formations compared to 2007 estimates. Table 2 shows the 2008 estimates and compares them to estimates from the 2007 version.

The Carbon Sequestration Atlas was compiled from estimates of geological storage capacity made by seven separate regional partnerships, government-industry collaborations fostered by DOE, that each produced estimates for different regions of the United States and parts of Canada. According to DOE, geographical differences in fossil fuel use and sequestration potential across the country led to a regional approach to assessing $\mathrm{CO}_{2}$ sequestration potential. ${ }^{33}$ The Carbon Sequestration Atlas reflects some of the regional differences; for example, not all of the regional partnerships identified unmineable coal seams as potential $\mathrm{CO}_{2}$ reservoirs. Other partnerships identified geological formations unique to their regions-such as organic-rich shales in the Illinois Basin, or flood basalts in the Columbia River Plateau - as other types of possible reservoirs for $\mathrm{CO}_{2}$ storage.

Table 2 indicates a lower and upper range for sequestration potential in deep saline formations and for unmineable coal seams, but only a single estimate for oil and gas fields. The 2007 Carbon Sequestration Atlas explained that a range of sequestration capacity for oil and gas reservoirs is not provided - in contrast to deep saline formations and coal seams-because of the relatively good understanding of oil and gas field volumetrics. ${ }^{34}$ Although it is widely accepted that oil and gas reservoirs are better understood, primarily because of the long history of oil and gas

${ }^{32}$ U.S. Dept. of Energy, National Energy Technology Laboratory, 2008 Carbon Sequestration Atlas of the United States and Canada, $2^{\text {nd }}$ ed. (November 2008), 140 pages. Hereafter referred to as the 2008 Carbon Sequestration Atlas. See http://www.netl.doe.gov/technologies/carbon_seq/refshelf/atlasII/.

${ }^{33} 2008$ Carbon Sequestration Atlas, p. 8.

${ }^{34} 2007$ Carbon Sequestration Atlas, p. 12. 
exploration and development, it seems unlikely that the capacity for $\mathrm{CO}_{2}$ storage in oil and gas formations is known to the level of precision stated in the 2008 Carbon Sequestration Atlas. It is likely that the estimate of $138 \mathrm{GtCO}_{2}$ shown in Table 2 may change, for example, pending the results of large-scale $\mathrm{CO}_{2}$ injection tests in oil and gas fields.

\section{Table 2. Geological Sequestration Potential for the United States and Parts of Canada}

(comparing 2008 and 2007 estimates, $\mathrm{GtCO}_{2}$ )

\begin{tabular}{|c|c|c|c|c|c|c|}
\hline $\begin{array}{l}\text { Reservoir } \\
\text { type }\end{array}$ & $\begin{array}{l}\text { Lower } \\
\text { estimate } \\
(2008)\end{array}$ & $\begin{array}{l}\text { Lower } \\
\text { estimate } \\
(2007)\end{array}$ & $\%$ change & $\begin{array}{c}\text { Upper } \\
\text { estimate } \\
(2008)\end{array}$ & $\begin{array}{c}\text { Upper } \\
\text { estimate } \\
(2007)\end{array}$ & $\%$ change \\
\hline $\begin{array}{l}\text { Oil and gas } \\
\text { fields }\end{array}$ & 138 & 82.4 & $+67 \%$ & - & - & - \\
\hline $\begin{array}{l}\text { Deep saline } \\
\text { formations }\end{array}$ & 3,297 & 919.0 & $+259 \%$ & 12,618 & $3,378.0$ & $+274 \%$ \\
\hline $\begin{array}{l}\text { Unmineable } \\
\text { coal seams }\end{array}$ & 157 & I 56.1 & $+0.6 \%$ & 178 & 183.5 & $-3.0 \%$ \\
\hline
\end{tabular}

Source: 2008 and 2007 Carbon Sequestration Atlases.

Each partnership produced its own estimates of reservoir capacity, and some observers have raised the issue of consistency among estimates across the regions. The Energy Independence and Security Act of 2007, enacted as P.L. 110-140 on December 19, 2007, directed the Department of the Interior (DOI) to develop a single methodology for an assessment of the national potential for geologic storage of carbon dioxide. Under P.L. 110-140, the U.S. Geological Survey (USGS) within DOI is directed to complete an assessment of the national capacity for $\mathrm{CO}_{2}$ storage in accordance with the methodology. The law gives the USGS two years following publication of the methodology to complete the national assessment. According to DOE, the USGS effort will allow refinement of the estimates provided in the 2008 Carbon Sequestration Atlas, and will incorporate uncertainty in the capacity estimates. ${ }^{35}$ The DOE Sequestration Atlas should probably be considered an evolving assessment of U.S. reservoir capacity for $\mathrm{CO}_{2}$ storage.

\section{Deep Ocean Sequestration}

The world's oceans contain approximately 50 times the amount of carbon stored in the atmosphere and nearly 10 times the amount stored in plants and soils. ${ }^{36}$ The oceans today take up - act as a net sink for-approximately $1.7 \mathrm{GtCO}_{2}$ per year. About $45 \%$ of the $\mathrm{CO}_{2}$ released from fossil fuel combustion and land use activities during the 1990s has remained in the atmosphere, while the remainder has been taken up by the oceans, vegetation, or soils on the land surface. ${ }^{37}$ Without the ocean sink, atmospheric $\mathrm{CO}_{2}$ concentration would be increasing more rapidly. Ultimately, the oceans could store more than $90 \%$ of all the carbon released to the

\footnotetext{
352008 Carbon Sequestration Atlas, p. 23.

${ }^{36}$ Christopher L. Sabine et al., "Current Status and Past Trends of the Global Carbon Cycle," in C. B. Field and M. R. Raupach, eds., The Global Carbon Cycle: Integrating Humans, Climate, and the Natural World (Washington, DC: Island Press, 2004), pp. 17-44.

${ }^{37} 2007$ IPCC Working Group I Report, pp. 514-515.
} 
atmosphere by human activities, but the process takes thousands of years. ${ }^{38}$ The ocean's capacity to absorb atmospheric $\mathrm{CO}_{2}$ may change, however, and possibly even decrease in the future. ${ }^{39}$ Also, studies indicate that as more $\mathrm{CO}_{2}$ enters the ocean from the atmosphere, the surface waters are becoming more acidic. ${ }^{40}$

\section{Advantages and Disadvantages}

Although the surface of the ocean is becoming more concentrated with $\mathrm{CO}_{2}$, the surface waters and the deep ocean waters generally mix very slowly, on the order of decades to centuries. Injecting $\mathrm{CO}_{2}$ directly into the deep ocean would take advantage of the slow rate of mixing, allowing the injected $\mathrm{CO}_{2}$ to remain sequestered until the surface and deep waters mix and $\mathrm{CO}_{2}$ concentrations equilibrate with the atmosphere. What happens to the $\mathrm{CO}_{2}$ would depend on how it is released into the ocean, the depth of injection, and the temperature of the seawater.

Carbon dioxide injected at depths shallower than 500 meters typically would be released as a gas, and would rise towards the surface. Most of it would dissolve into seawater if the injected $\mathrm{CO}_{2}$ gas bubbles were small enough. ${ }^{41}$ At depths below 500 meters, $\mathrm{CO}_{2}$ can exist as a liquid in the ocean, although it is less dense than seawater. After injection below 500 meters, $\mathrm{CO}_{2}$ would also rise, but an estimated 90\% would dissolve in the first 200 meters. Below 3,000 meters in depth, $\mathrm{CO}_{2}$ is a liquid and is denser than seawater; the injected $\mathrm{CO}_{2}$ would sink and dissolve in the water column or possibly form a $\mathrm{CO}_{2}$ pool or lake on the sea bottom. Some researchers have proposed injecting $\mathrm{CO}_{2}$ into the ocean bottom sediments below depths of 3,000 meters, and immobilizing the $\mathrm{CO}_{2}$ as a dense liquid or solid $\mathrm{CO}_{2}$ hydrate. ${ }^{42}$ Deep storage in ocean bottom sediments, below 3,000 meters in depth, might potentially sequester $\mathrm{CO}_{2}$ for thousands of years. ${ }^{43}$

The potential for ocean storage of captured $\mathrm{CO}_{2}$ is huge, but environmental impacts on marine ecosystems and other issues may determine whether large quantities of captured $\mathrm{CO}_{2}$ will ultimately be stored in the oceans. Also, deep ocean storage is in a research stage, and the effects of scaling up from small research experiments, using less than 100 liters of $\mathrm{CO}_{2},{ }^{44}$ to injecting several $\mathrm{GtCO}_{2}$ into the deep ocean are unknown.

Injecting $\mathrm{CO}_{2}$ into the deep ocean would change ocean chemistry, locally at first, and assuming that hundreds of $\mathrm{GtCO}_{2}$ were injected, would eventually produce measurable changes over the

\footnotetext{
${ }^{38} \mathrm{CO}_{2}$ forms carbonic acid when dissolved in water. Over time, the solid calcium carbonate $\left(\mathrm{CaCO}_{3}\right)$ on the seafloor will react with, or neutralize, much of the carbonic acid that entered the oceans as $\mathrm{CO}_{2}$ from the atmosphere. See David Archer et al., "Dynamics of fossil fuel $\mathrm{CO}_{2}$ neutralization by marine $\mathrm{CaCO}_{3}$," Global Biogeochemical Cycles, vol. 12, no. 2 (June 1998): pp. 259-276.

${ }^{39}$ One study, for example, suggests that the efficiency of the ocean sink has been declining at least since 2000; see Josep G. Canadell et al., "Contributions to accelerating atmospheric $\mathrm{CO}_{2}$ growth from economic activity, carbon intensity, and efficiency of natural sinks," PNAS, vol. 47, no. 104 (November 20, 2007), pp. 18866-18870.

${ }^{40}$ For more information on ocean acidification, see CRS Report R40143, Ocean Acidification, by Eugene H. Buck and Peter Folger.

${ }^{41}$ IPCC Special Report, p. 285.

${ }^{42} \mathrm{~A} \mathrm{CO}_{2}$ hydrate is a crystalline compound formed at high pressures and low temperatures by trapping $\mathrm{CO}_{2}$ molecules in a cage of water molecules.

${ }^{43}$ K. Z. House, et al., "Permanent carbon dioxide storage in deep-sea sediments," Proceedings of the National Academy of Sciences, vol. 103, no. 33 (Aug. 15, 2006): pp. 12291-12295.

${ }^{44}$ P. G. Brewer, et al., "Deep ocean experiments with fossil fuel carbon dioxide: creation and sensing of a controlled plume at 4 km depth," Journal of Marine Research, vol. 63, no. 1 (2005): p. 9-33.
} 
entire ocean. ${ }^{45}$ The most significant and immediate effect would be the lowering of $\mathrm{pH}$, increasing the acidity of the water. A lower $\mathrm{pH}$ may harm some ocean organisms, depending on the magnitude of the $\mathrm{pH}$ change and the type of organism. Actual impacts of deep sea $\mathrm{CO}_{2}$ sequestration are largely unknown, however, because scientists know very little about deep ocean ecosystems. ${ }^{46}$

Environmental concerns led to the cancellation of the largest planned experiment to test the feasibility of ocean sequestration in 2002. A scientific consortium had planned to inject $60 \mathrm{tCO}_{2}$ into water over 800 meters deep near the Kona coast on the island of Hawaii. Environmental organizations opposed the experiment on the grounds that it would acidify Hawaii's fishing grounds, and that it would divert attention from reducing greenhouse gas emissions. ${ }^{47} \mathrm{~A}$ similar but smaller project with plans to release more than $5 \mathrm{tCO}_{2}$ into the deep ocean off the coast of Norway, also in 2002, was cancelled by the Norway Ministry of the Environment after opposition from environmental groups. ${ }^{48}$

\section{Mineral Carbonation}

Another option for sequestering $\mathrm{CO}_{2}$ produced by fossil fuel combustion involves converting $\mathrm{CO}_{2}$ to solid inorganic carbonates, such as $\mathrm{CaCO}_{3}$ (limestone), using chemical reactions. When this process occurs naturally it is known as "weathering" and takes place over thousands or millions of years. The process can be accelerated by reacting a high concentration of $\mathrm{CO}_{2}$ with minerals found in large quantities on the Earth's surface, such as olivine or serpentine. ${ }^{49}$ Mineral carbonation has the advantage of sequestering carbon in solid, stable minerals that can be stored without risk of releasing carbon to the atmosphere over geologic time scales.

Mineral carbonation involves three major activities: (1) preparing the reactant minerals-mining, crushing, and milling - and transporting them to a processing plant, (2) reacting the concentrated $\mathrm{CO}_{2}$ stream with the prepared minerals, and (3) separating the carbonate products and storing them in a suitable repository.

\section{Advantages and Disadvantages}

Mineral carbonation is well understood and can be applied at small scales, but is at an early phase of development as a technique for sequestering large amounts of captured $\mathrm{CO}_{2}$. Large volumes of silicate oxide minerals are needed, from 1.6 to 3.7 metric tons of silicates per $\mathrm{tCO}_{2}$ sequestered. Thus, a large-scale mineral carbonation process needs a large mining operation to provide the reactant minerals in sufficient quantity. ${ }^{50}$ Large volumes of solid material would also be produced, between 2.6 and 4.7 metric tons of materials per $\mathrm{tCO}_{2}$ sequestered, or 50\%-100\% more material

\footnotetext{
${ }^{45}$ IPCC Special Report, p. 279.

${ }^{46}$ Ibid., p. 298.

${ }^{47}$ Virginia Gewin, “Ocean carbon study to quit Hawaii,” Nature, vol. 417 (June 27, 2002): p. 888.

${ }^{48}$ Jim Giles, “Norway sinks ocean carbon study,” Nature, vol. 419 (Sept. 5, 2002): p. 6.

${ }^{49}$ Serpentine and olivine are silicate oxide minerals—combinations of the silica, oxygen, and magnesium-that react with $\mathrm{CO}_{2}$ to form magnesium carbonates. Wollastonite, a silica oxide mineral containing calcium, reacts with $\mathrm{CO}_{2}$ to form calcium carbonate (limestone). Magnesium and calcium carbonates are stable minerals over long time scales.

${ }^{50}$ IPCC Special Report, p. 40.
} 
to be disposed of by volume than originally mined. Because mineral carbonation is in the research and experimental stage, estimating the amount of $\mathrm{CO}_{2}$ that could be sequestered by this technique is difficult.

One possible geological reservoir for $\mathrm{CO}_{2}$ storage-major flood basalts ${ }^{51}$ such as those on the Columbia River Plateau-is being explored for its potential to react with $\mathrm{CO}_{2}$ and form solid carbonates in situ (in place). Instead of mining, crushing, and milling the reactant minerals, as discussed above, $\mathrm{CO}_{2}$ would be injected directly into the basalt formations and would react with the rock over time and at depth to form solid carbonate minerals. Large and thick formations of flood basalts occur globally, and many have characteristics - such as high porosity and permeability-that are favorable to storing $\mathrm{CO}_{2}$. Those characteristics, combined with tendency of basalt to react with $\mathrm{CO}_{2}$, could result in a large-scale conversion of the gas into stable, solid minerals that would remain underground for geologic time. One of the DOE regional carbon sequestration partnerships is exploring the possibility for using Columbia River Plateau flood basalts for storing $\mathrm{CO}_{2}$; however, investigations are in a preliminary stage. ${ }^{52}$

\section{Costs for CCS}

Cost estimates for CCS typically present a range of values and depend on many variables, such as the type of capture technology (post-combustion, pre-combustion, oxy-fuel), whether the plant represents new construction or is a retrofit to an existing plant, whether the CCS project is in a demonstration or a commercial stage, and a variety of other factors. Part of the difficulty in estimating costs is the lack of any operating, commercial-scale electricity-generating power plants that capture and sequester their $\mathrm{CO}_{2}$ emissions. Thus, there are no real-world examples to draw from. In addition, there is neither a market price for $\mathrm{CO}_{2}$ emitted nor a regulatory requirement to capture $\mathrm{CO}_{2}$ - a market demand — which would likely shape cost estimates. All observers, however, agree that installing $\mathrm{CO}_{2}$ capture technology will increase the cost of generating electricity from fossil fuel power plants. As a result, few companies are likely to commit to the extra expense of installing technology to capture $\mathrm{CO}_{2}$, or installing the infrastructure to transport and store it, until they are required to do so.

Despite these challenges, several studies have estimated costs for CCS, in the likelihood that desire for lower $\mathrm{CO}_{2}$ emissions and continued demand for electricity from fossil fuel power plants converge and foster development and deployment of CCS. According to one DOE estimate, sequestration costs for capture, transport, and storage range from $\$ 27$ to $\$ 82$ per metric ton of $\mathrm{CO}_{2}$ emissions avoided using present technology. ${ }^{53}$ In a 2007 study, MIT estimated how much the cost of generating electricity would increase if $\mathrm{CO}_{2}$ capture technology were installed, both for new plants and for retrofits of existing plants. Table $\mathbf{3}$ shows the MIT estimates.

\footnotetext{
${ }^{51}$ Flood basalts are vast expanses of solidified lava, commonly containing olivine, that erupted over large regions in several locations around the globe. In addition to the Columbia River Plateau flood basalts, other well-known flood basalts include the Deccan Traps in India and the Siberian Traps in Russia.

522008 Carbon Sequestration Atlas, p. 35.

${ }^{53}$ Equivalent to $\$ 100$ to $\$ 300$ per metric ton of carbon emissions avoided; see http://www.fossil.energy.gov/programs/ sequestration/overview.html.
} 
Table 3. Estimates of Additional Costs of Selected Carbon Capture Technology (percent increase in electric generating costs on levelized basis)

\begin{tabular}{lcc}
\hline & New Construction & Retrofita $^{\circ}$ \\
\hline Post-combustion & $60 \%-70 \%$ & $220 \%-250 \%$ \\
Pre-combustion & $22 \%-25 \%$ & not applicable \\
Oxy-fuel & $46 \%$ & $170 \%-206 \%$ \\
\hline
\end{tabular}

Source: Massachusetts Institute of Technology, The Future of Coal: An Interdisciplinary MIT Study (2007), Pp. 27, $30,36,149$.

a. Assumes capital costs have been fully amortized.

In most carbon sequestration systems, the cost of capturing $\mathrm{CO}_{2}$ is the largest component, possibly accounting for as much as $80 \%$ of the total. ${ }^{54}$ In a 2008 study by McKinsey \& Company, capture costs accounted for the majority of CCS costs estimated for demonstration plants and early commercial plants. ${ }^{55}$ Table 4 shows the McKinsey \& Company estimates for three different stages of CCS development for new, coal-fired power plants.

Table 4. Estimates of CCS Costs at Different Stages of Development (dollars per metric ton of $\mathrm{CO}_{2}$, for new coal-fired powerplants)

\begin{tabular}{lcccc}
\hline & Capture & Transport & Storage & Total \\
\hline $\begin{array}{l}\text { Initial } \\
\text { demonstration }\end{array}$ & $\$ 73-\$ 94$ & $\$ 7-\$ 22$ & $\$ 6-\$ 17$ & $\$ 86-\$ 133$ \\
$\begin{array}{l}\text { Early commercial } \\
\begin{array}{l}\text { Past early } \\
\text { commercial }\end{array}\end{array}$ & $\$ 36-\$ 46$ & $\$ 6-\$ 9$ & $\$ 6-\$ 17$ & $\$ 48-\$ 73$ \\
\hline
\end{tabular}

Source: McKinsey \& Company, Carbon Capture and Storage: Assessing the Economics, Sept. 22, 2008.

Notes: Source provided cost estimates in Euros. Euros converted to dollars at I Euro $=\$ 1.45$, rounded to nearest dollar.

a. Cost ranges for capture, transport, and storage components for past early commercial-stage plants are not available from this study.

The MIT and McKinsey \& Company studies both suggest that retrofitting power plants would lead to more expensive CCS costs, in general, compared to new plants on a levelized basis. Four reasons for higher costs include (1) the added expense of adapting the existing plant configuration for the capture unit; (2) a shorter lifespan for the capture unit compared to new plants; (3) a higher efficiency penalty compared to new plants that incorporate $\mathrm{CO}_{2}$ capture from the design stage; and (4) the generating time lost when an existing plant is taken off-line for the retrofit. ${ }^{56}$ Retrofitted plants could be less expensive if capture technology is installed on new plants that were designed "capture-ready," or if an older plant was already due for extensive revamping. ${ }^{57}$

${ }^{54}$ Furnival, "Burying Climate Change for Good."

${ }^{55}$ McKinsey \& Company, Carbon Capture and Storage: Assessing the Economics, Sept. 22, 2008, at http://www.mckinsey.com/clientservice/ccsi/pdf/CCS_Assessing_the_Economics.pdf.

${ }^{56}$ McKinsey \& Company, p. 29.

${ }^{57}$ Ibid., p. 30. 
As these cost estimates indicate, capturing $\mathrm{CO}_{2}$ at electricity-generating power plants would likely require more energy, per unit of power output, than is required by plants without CCS, reducing the plant efficiency. The additional energy required also means that more $\mathrm{CO}_{2}$ would be produced, per unit of power output. (See Appendix B.) Improving the efficiency of the $\mathrm{CO}_{2}$ capture phase would likely produce the largest cost savings and reduce $\mathrm{CO}_{2}$ emissions. Costs for each CCS project would probably not be uniform, however, even for those employing the same type of capture technology. Other site-specific factors, such as types and costs of fuels used by power plants, distance of transport to a storage site, and the type of $\mathrm{CO}_{2}$ storage, would likely vary from project to project.

\section{The DOE Carbon Capture and Sequestration Program}

The DOE CCS program has had three main elements: (1) core research and development, consisting of laboratory and pilot-scale research for developing new technologies and systems for greenhouse gas mitigation; (2) demonstration and deployment, consisting of demonstration projects to test the viability of large-scale CCS technologies using regional partnerships; and (3) support for the DOE FutureGen project. ${ }^{58}$ FutureGen was a 10 -year initiative to build a near-zero emissions integrated carbon sequestration and hydrogen production power plant. DOE announced on January 30, 2008, that the focus for FutureGen would shift away from its original concept, a decision that sparked some controversy and led to efforts to restore funding for a near zeroemission plant or plants (see below).

According to DOE, the overall goal of the CCS program is to develop, by 2012, systems that will achieve $90 \%$ capture of $\mathrm{CO}_{2}$ at less than a $10 \%$ increase in the cost of energy services and retain $99 \%$ storage permanence. ${ }^{59}$ The research aspect of the DOE program includes a combination of cost-shared projects, industry-led development projects, research grants, and research at the National Energy Technology Laboratory. The program investigates five focus areas: (1) $\mathrm{CO}_{2}$ capture; (2) carbon storage; (3) monitoring, mitigation, and verification; (4) work on non- $\mathrm{CO}_{2}$ greenhouse gases; and (5) advancing breakthrough technologies.

After the 2007 DOE roadmap and program plan was made available, Congress passed the Energy Independence and Security Act of 2007 (P.L. 110-140), which authorized an expansion of the DOE carbon sequestration research and development program and increased its emphasis on large-scale underground injection and storage experiments in geologic reservoirs. The American Recovery and Reinvestment Act (ARRA) of 2009 provides up to \$3.4 billion for CCS-related activities at DOE through FY2010, which will likely alter DOE's CCS program priorities over that time frame, although which specific projects and programs will receive funding is not clear (see discussion of ARRA above).

\footnotetext{
${ }^{58}$ DOE Carbon Sequestration Technology Roadmap and Program Plan 2007, p. 8. See http://www.netl.doe.gov/technologies/carbon_seq/refshelf/project\%20portfolio/2007/2007Roadmap.pdf.

${ }^{59}$ Ibid., p. 5.
} 


\section{DOE CCS Research and Development Funding Through FY2008}

The federal government has recognized the potential need for CCS technology—as part of broader efforts to address greenhouse-gas induced climate change-since at least 1997, when DOE spent approximately $\$ 1$ million for the entire CCS program. ${ }^{60}$ DOE spending on the CCS program has increased over the 11-year period to its highest amount in FY2008 of \$118.9 million. ${ }^{61}$ If DOE spending for FutureGen is included, together with carbon-capture technology investments through the Innovations for Existing Plants (IEP) and the Advanced Integrated Gasification Combined Cycle (AIGCC) programs (also within the DOE Office of Fossil Energy), then CCS spending at DOE would equal nearly $\$ 283$ million for FY2008. ${ }^{62}$ If the Bush Administration's budget request for FY2009 were fully funded, then overall spending for CCS R\&D could equal $\$ 414$ million, a $46 \%$ increase over FY2008 spending levels. As noted above, funding provided under ARRA will likely increase funding for CCS-related programs dramatically above FY2008 levels.

\section{Loan Guarantees and Tax Credits}

Appropriations represent one mechanism for funding carbon capture technology R\&D; others include loan guarantees and tax credits, both of which are available under current law. Loan guarantee incentives that could be applied to CCS are authorized under Title XVII of the Energy Policy Act of 2005 (EPAct2005, P.L. 109-58). Title XVII of EPAct2005 (42 U.S.C. 16511-16514) authorizes the Secretary of Energy to make loan guarantees for projects that, among other purposes, avoid, reduce, or sequester air pollutants or anthropogenic emissions of greenhouse gases. The Consolidated Appropriations Act for FY2008 (P.L. 110-161) provided loan guarantees authorized by EPAct 2005 for coal-based power generation and industrial gasification activities that incorporate CCS, as well as for advanced coal gasification. The explanatory statement accompanying P.L. 110-161 directed allocation of \$6 billion in loan guarantees for retrofitted and new facilities that incorporate CCS or other beneficial uses of carbon. ${ }^{63}$

Title XIII of EPAct2005 provides for tax credits that can be used for Integrated Gasification Combined Cycle (IGCC) projects and for projects that use other advanced coal-based generation technologies (ACBGT). For these types of projects, the aggregate credits available total up to $\$ 1.3$ billion: $\$ 800$ million for IGCC projects, and \$500 million for ACBGT projects. Qualifying projects under Title XIII of EPAct2005 are not limited to technologies that employ carbon capture technologies, but the Secretary of the Treasury is directed to give high priority to projects that include greenhouse gas capture capability. Under the same title of EPAct2005, certain projects employing gasification technology ${ }^{64}$ would be eligible to receive up to $\$ 650$ million in tax credits,

\footnotetext{
${ }^{60}$ Personal communication, Timothy E. Fout, General Engineer, DOE National Energy Technology Laboratory, Morgantown, WV (July 16, 2008).

${ }^{61} \mathrm{CCS}$ research and development program line item in the DOE budget (part of the Office of Fossil Energy), U.S. Department of Energy, FY2009 Congressional Budget Request, Volume 7, DOE/CF-030 (Washington, DC, February 2008).

${ }^{62}$ Ibid.

${ }^{63}$ The explanatory statement was published with the committee print of the House Committee on Appropriations, Consolidated Appropriations Act, 2008, H.R. 2764/P.L. 110-161. The committee print, which was published in January 2008, is available at http://www.gpoaccess.gov/congress/house/appropriations/08conappro.html.

${ }^{64}$ Under Title XIII of EPAct2005, gasification technology means any process that converts a solid or liquid product from coal, petroleum residue, biomass, or other materials, which are recovered for their energy or feedstock value, into a synthesis gas (composed primarily of carbon monoxide and hydrogen) for direct use in the production of energy or (continued...)
} 
and these projects would also receive high priority from the Secretary of the Treasury if they include greenhouse gas capture technology.

\section{Regional Carbon Sequestration Partnerships}

Beginning in 2003, DOE created seven regional carbon sequestration partnerships to identify opportunities for carbon sequestration field tests in the United States and Canada. ${ }^{65}$ The regional partnerships program is being implemented in a three-phase overlapping approach: (1) characterization phase (from FY2003 to FY2005); (2) validation phase (from FY2005 to FY2009); and (3) deployment phase (from FY2008 to FY2017). ${ }^{66}$

The third phase, deployment, is intended to demonstrate large-volume, prolonged injection and $\mathrm{CO}_{2}$ storage in a wide variety of geologic formations. According to DOE, this phase is to address the practical aspects of large-scale operations, with an aim toward producing the results necessary for commercial CCS activities to move forward. On November 17, 2008, DOE announced it was awarding the seventh, and last, award for the large-scale carbon sequestration projects under phase three. ${ }^{67}$ DOE has now awarded funds totaling $\$ 457.6$ million (an average of $\$ 65$ million per project) to conduct a variety of large-scale injection tests over several years. In addition to DOE funding, each partnership also contributes funds ranging from $21 \%$ to over $50 \%$ of the total project costs. $^{68}$

\section{FutureGen}

On February 27, 2003, President Bush proposed a 10-year, $\$ 1$ billion project to build a coal-fired power plant that integrates carbon sequestration and hydrogen production while producing 275 megawatts of electricity, enough to power about 150,000 average U.S. homes. As originally conceived, the plant would have been a coal-gasification facility and would have produced and sequestered between 1 and $2 \mathrm{MtCO}_{2}$ annually. On January 30, 2008, DOE announced that it was "restructuring" the FutureGen program away from a single, state-of-the-art "living laboratory" of integrated R\&D technologies - a single plant - to instead pursue a new strategy of multiple commercial demonstration projects. ${ }^{69}$ In the restructured program, DOE would support up to two or three demonstration projects of at least 300 megawatts and that would sequester at least 1 $\mathrm{MtCO}_{2}$ per year.

\footnotetext{
(...continued)

for subsequent conversion to another product.

${ }^{65}$ The seven partnerships are Midwest Regional Carbon Sequestration Partnership; Midwest (Illinois Basin) Geologic Sequestration Consortium; Southeast Regional Carbon Sequestration Partnership; Southwest Regional Carbon Sequestration Partnership; West Coast Regional Carbon Sequestration Partnership; Big Sky Regional Carbon Sequestration Partnership; and Plains $\mathrm{CO}_{2}$ Reduction Partnership; see http://www.fossil.energy.gov/programs/ sequestration/partnerships/index.html.

${ }^{66}$ DOE Carbon Sequestration Technology Roadmap and Program Plan 2007, p. 36.

${ }^{67}$ DOE awarded $\$ 66.9$ million to the Big Sky Carbon Sequestration Partnership. See http://www.fossil.energy.gov/news/techlines/2008/08059-DOE_Makes_Sequestration_Award.html.

${ }^{68}$ For more information about specific sequestration projects, see the DOE Carbon Sequestration Regional Partnerships website, at http://www.fossil.energy.gov/programs/sequestration/partnerships/index.html.

${ }^{69}$ See http://www.fossil.energy.gov/news/techlines/2008/08003-DOE_Announces_Restructured_FutureG.html.
} 
In its budget justification for FY2009, DOE cited "new market realities" for its decision, namely rising material and labor costs for new power plants, and the need to demonstrate commercial viability of Integrated Gasification Combined Cycle (IGCC) power plants with CCS. ${ }^{70}$ The budget justification also noted that a number of states are making approval of new power plants contingent on provisions to control $\mathrm{CO}_{2}$ emissions, further underscoring the need to demonstrate commercial viability of a new generation of coal-based power systems, according to DOE. For FY2009, DOE requested \$156 million for the restructured program, and specified that the federal cost-share would only cover the CCS portions of the demonstration projects, not the entire power system.

Prior to DOE's announced restructuring of the program, the FutureGen Alliance-an industry consortium of 13 companies-announced on December 18, 2007, that it had selected Mattoon, IL, as the host site from a set of four finalists. ${ }^{71}$ In its January 30, 2008, announcement, DOE stated that the four finalist locations may be eligible to host an IGCC plant with CCS under the new program.

In the debate leading up to enactment of ARRA, the Senate amendment to H.R. 1 (known as the Collins-Nelson amendment) contained language under Fossil Energy Research and Development that made $\$ 2$ billion "available for one or more near zero emissions powerplant(s)." ${ }^{, 72}$ Some observers noted that the language may refer to a plant or plants similar to the original conception for FutureGen, although the Senate amendment did not refer either to FutureGen or to a specific location where the plant would be built. The language referring to zero-emissions power plant(s) was removed in conference and is not included in the conference report to accompany P.L. 111-5 (ARRA).

\section{Issues for Congress}

A primary goal of developing and deploying CCS is to allow large industrial facilities, such as fossil fuel power plants and cement plants, to operate while reducing their $\mathrm{CO}_{2}$ emissions by $80 \%-90 \%$. Such reductions would presumably reduce the likelihood of continued climate warming from greenhouse gases by slowing the rise in atmospheric concentrations of $\mathrm{CO}_{2}$ (atmospheric $\mathrm{CO}_{2}$ concentrations grew at an annual rate of 3.2\% for the first five years of this decade, faster than the annual rate during the 1990s). To achieve the overarching goal of reducing the likelihood of continued climate warming would depend, in part, on how fast and how widespread CCS could be deployed throughout the economy.

Congress has supported CCS R\&D for over 10 years and DOE spending increased substantially in FY2007 and FY2008 compared to previous years. The American Recovery and Reinvestment Act of 2009 (P.L. 111-5) increases that trend markedly, adding an additional \$3.4 billion in CCSrelated federal obligations through FY2010. It is likely that the large increase in funding will accelerate technological development of CCS systems.

\footnotetext{
${ }^{70}$ DOE FY2009 Budget Request, p. 16.

${ }^{71}$ The four were Mattoon, IL; Tuscola, IL; Heart of Brazos (near Jewett, TX); and Odessa, TX.

${ }^{72}$ See http://appropriations.senate.gov/News/2009_02_09_Substitute_Amendment_to_HR1_\%7BCollins_Nelson_ Amendment\%7D.pdf?CFID=23617867\&CFTOKEN=75628290.
} 
The timeline for developing systems to capture and sequester $\mathrm{CO}_{2}$, however, differs from when CCS technologies may become available for large-scale deployment and are actually deployed. In testimony before the Senate Energy and Natural Resources Committee on April 16, 2007, Thomas D. Shope, Acting Assistant Secretary for Fossil Energy at DOE, stated that under current (2007) budget constraints and outlooks CCS technologies would be available and deployable in the 2020 to 2025 timeframe. However, Mr. Shope added that "we're not going to see common, everyday deployment [of those technologies] until approximately 2045." ${ }^{, 73}$ With enactment of ARRA, the budget constraints now are likely very different compared to when Mr. Shope testified in 2007; nevertheless, Congress faces several challenges to the rapid and widespread deployment of CCS.

The dramatic increase in CCS R\&D funding provided for in ARRA will likely invite scrutiny of the relative roles of research, development, and deployment (technology-push mechanisms) versus the requirement for a successful technology to be fully commercialized. To achieve commercialization, the technology must also meet a market demand-a demand created either through a price mechanism or a regulatory requirement (demand-pull mechanisms). Even if technologies for capturing large amounts of $\mathrm{CO}_{2}$ become more efficient and cheaper, few companies are likely to install such technologies until they are required to do so.

Major increases in capture technology efficiency will likely produce the greatest relative cost savings for CCS systems, but challenges also face the transportation and storage components of CCS. Ideally, storage reservoirs for $\mathrm{CO}_{2}$ would be located close to sources, obviating the need to build a large pipeline infrastructure to deliver captured $\mathrm{CO}_{2}$ for underground sequestration. If CCS moves to widespread implementation, however, some areas of the country may not have adequate reservoir capacity nearby, and may need to construct pipelines from sources to reservoirs. Identifying and validating sequestration sites would need to account for $\mathrm{CO}_{2}$ pipeline costs, for example, if the economics of the sites are to be fully understood. If this is the case, there would be questions to be resolved regarding pipeline network requirements, economic regulation, utility cost recovery, regulatory classification of $\mathrm{CO}_{2}$ itself, and pipeline safety.

Although DOE has identified substantial potential storage capacity for $\mathrm{CO}_{2}$, particularly in deep saline formations, large-scale injection experiments are only beginning in the United States to test how different types of reservoirs perform during $\mathrm{CO}_{2}$ injection. Data from the upcoming experiments will undoubtedly be crucial to future permitting and site approval regulations; however, no existing federal regulations govern the injection and storage of $\mathrm{CO}_{2}$ for the purposes of carbon sequestration. In July 2008, the U.S. Environmental Protection Agency (EPA) released a draft rule that would regulate $\mathrm{CO}_{2}$ injection for the purposes of geological sequestration under the authority of the Safe Drinking Water Act, Underground Injection Control (UIC) program. ${ }^{74}$ Some observers have noted that regulating $\mathrm{CO}_{2}$ injection solely to protect groundwater, which is the focus of the UIC rulemaking process, may not fully address the primary purpose of storing $\mathrm{CO}_{2}$ underground, which is to reduce atmospheric concentrations. ${ }^{75}$

\footnotetext{
${ }^{73}$ Testimony of Thomas D. Shope, Acting Assistant Secretary for Fossil Energy, DOE, before the Senate Energy and Natural Resources Committee, Apr. 16, 2007; at http://frwebgate.access.gpo.gov/cgi-bin/ getdoc.cgi?dbname=110_senate_hearings\&docid=f:36492.pdf.

${ }^{74}$ Federal Register, pages 43,491-43,541 (July 25, 2008).

${ }^{75}$ See, for example, Carbon Capture and Sequestration: Framing the Issues for Regulation, an Interim Report from the CCSReg Project (December 2008), pp. 73-90; at http://www.ccsreg.org/interimreport/feedback.php.
} 
In addition, liability, ownership, and long-term stewardship for $\mathrm{CO}_{2}$ sequestered underground are issues that would need to be resolved before CCS is deployed commercially. Some states are moving ahead with state-level geological sequestration regulations for $\mathrm{CO}_{2}$, so federal efforts to resolve these issues at a national level would likely involve negotiations with the states. In addition, acceptance by the general public of large-scale deployment of CCS may be a significant challenge if the majority of CCS projects involve private land. ${ }^{76}$ Some of the large-scale injection tests could garner information about public acceptance, as local communities become familiar with the concept, process, and results of $\mathrm{CO}_{2}$ injection tests. Apart from the question of how the public would accept the likely higher cost for electricity generated from plants with CCS, how a growing CCS infrastructure of pipelines, injection wells, underground reservoirs, and other facilities would be accepted by the public is as yet unknown.

${ }^{76}$ For more information on public acceptance of CCS, see CRS Report RL34601, Community Acceptance of Carbon Capture and Sequestration Infrastructure: Siting Challenges, by Paul W. Parfomak. 


\section{Appendix A. Carbon Sequestration Legislation in the $110^{\text {th }}$ Congress}

\section{The Energy Independence and Security Act of 2007}

P.L. 110-140, the Energy Independence and Security Act of 2007, authorized an expansion of the current federal carbon sequestration research and development program at DOE and placed an increased emphasis on large-scale underground injection and storage experiments. Title VII, Subtitle A, § 702, required that DOE conduct at least seven large-volume sequestration tests of 1 million metric tons of carbon $\left(\mathrm{MtCO}_{2}\right)$ or more, in addition to conducting fundamental science and engineering research that would apply to developing CCS technologies. Appropriations to carry out activities under $\$ 702$ were authorized at $\$ 240$ million per year for FY2008-FY2012, a total of $\$ 1.2$ billion over five years.

Section 703 of Title VII authorized a program for projects that would demonstrate technologies for large-scale capture of $\mathrm{CO}_{2}$, from a range of industrial sources, as well as for transporting and injecting $\mathrm{CO}_{2}$, and provided for integrating the demonstration program with activities authorized under $\S 702$. Appropriations for the demonstration program under $\S 703$ were authorized at $\$ 200$ million per year for FY2009-FY2013, a total of \$1 billion over five years. Together, $\$ \S 702$ and 703 authorized a total of $\$ 2.2$ billion through FY2013.

Under Title VII, $\S 704$, the National Academy of Science (NAS) is to review the expanded R\&D program beginning in 2011. Under $\S 705$, DOE is to arrange with NAS to undertake a study to develop interdisciplinary graduate degree programs with an emphasis in geologic sequestration science. Section 708 establishes a university-based R\&D program to study CCS using various types of coal.

Under the act, injection and sequestration activities under Subtitle A are subject to requirements of the Safe Drinking Water Act. Further, the U.S. Environmental Protection Agency is directed to assess potential impacts of carbon sequestration on public health, safety, and the environment.

Under Subtitle B of Title VII, $\S 711$ directed the Department of the Interior (DOI) to develop a methodology for an assessment of the national potential for geologic storage of carbon dioxide. Not later than two years following publication of the methodology, DOI was directed to complete an assessment of national capacity for $\mathrm{CO}_{2}$ storage in accordance with the methodology. Section 711 authorized a total of \$30 million for FY2008-FY2012 for DOI to complete the assessment and submit its findings to Congress. In addition to completing a national assessment of $\mathrm{CO}_{2}$ storage capacity, DOI under $\S 714$ is to submit a report on a recommended regulatory framework for managing geologic carbon sequestration on public lands. The report is to include

- an assessment of options to ensure the United States receives fair market value for the use of public land;

- proposed procedures for public review and comment;

- procedures for protecting natural and cultural resources of the public land overlying the geologic sequestration sites; 
- a description of the status of liability issues related to the storage of carbon dioxide in public land;

- identification of legal and regulatory issues for cases where the United States owns title to the mineral resources but not the overlying land;

- identification of issues related to carbon dioxide pipeline rights-of-way; and

- recommendations for additional legislation that may be required for adequate public land management and leasing to accommodate geologic sequestration of carbon dioxide and pipeline rights-of-way.

\section{Other Selected CCS-Related Legislation in the $110^{\text {th }}$ Congress}

Bills introduced in the $110^{\text {th }}$ Congress that proposed cap-and-trade programs to reduce emissions of greenhouse gases also contained provisions addressing geologic sequestration. Of these, $\mathrm{S}$. 2191, sponsored by Senators Lieberman and Warner, was reported by the Senate Environment and Public Works Committee on May 20, 2008. A new version of the bill, S. 3036-identical to S. 2191 but containing a deficit reduction amendment aimed at making the bill revenue-neutralwas introduced on May 20 and a cloture motion was filed on May 22, 2008. On June 2, 2008, the Senate invoked cloture on the motion to proceed, allowing discussion of the bill, but not allowing amendments. A vote on June 6 failed to invoke cloture to end debate on the bill.

S. 3036 would have capped emissions of greenhouse gases $19 \%$ below 2005 levels by 2020, and $63 \%$ below 2005 levels by 2050 . The bill would have allocated a portion of bonus emission allowances $^{77}$ on the basis of carbon sequestration. Under Title III, Subtitle F, of the bill, each qualifying project would have initially received allowances equal to the number of metric tons of $\mathrm{CO}_{2}$ sequestered multiplied by 4.5 . The multiplier would have decreased steadily from 2017 to 2031 , and remained at 0.5 until 2039. For example, qualifying projects that geologically sequester $1 \mathrm{MtCO}_{2}$ in 2012 would have been eligible to receive 4,500,000 emission allowances. After 2031 and until 2039, qualifying projects that sequester $1 \mathrm{MtCO}_{2}$ could have received 500,000 emission allowances.

Provisions such as Title III, Subtitle F, in S. 3036 are intended to provide an incentive to develop and deploy CCS to help mitigate $\mathrm{CO}_{2}$ emissions. In the $111^{\text {th }}$ Congress, comprehensive cap-andtrade bills are likely to contain similar types of incentives for CCS.

\footnotetext{
${ }^{77}$ An emission allowance, as defined in S. 2191, means authorization to emit $1 \mathrm{CO}_{2}$ equivalent of greenhouse gas. One $\mathrm{CO}_{2}$ equivalent is defined as the quantity of greenhouse gas that makes the same contribution to global warming as 1 $\mathrm{MtCO}_{2}$.
} 


\section{Appendix B. Avoided $\mathrm{CO}_{2}$}

Figure B-1 compares captured $\mathrm{CO}_{2}$ and avoided $\mathrm{CO}_{2}$ emissions. Additional energy required for capture, transport, and storage of $\mathrm{CO}_{2}$ results in additional $\mathrm{CO}_{2}$ production from a plant with CCS. The lower bar in Figure B-1 shows the larger amount of $\mathrm{CO}_{2}$ produced per unit of power $(\mathrm{kWh})$ relative to the reference plant (upper bar) without CCS. Unless no additional energy is required to capture, transport, and store $\mathrm{CO}_{2}$, the amount of $\mathrm{CO}_{2}$ avoided is always less than the amount of $\mathrm{CO}_{2}$ captured. Thus the cost per $\mathrm{tCO}_{2}$ avoided is always more than the cost per $\mathrm{tCO}_{2}$ captured. ${ }^{78}$

Figure B-I.Avoided Versus Captured $\mathrm{CO}_{2}$

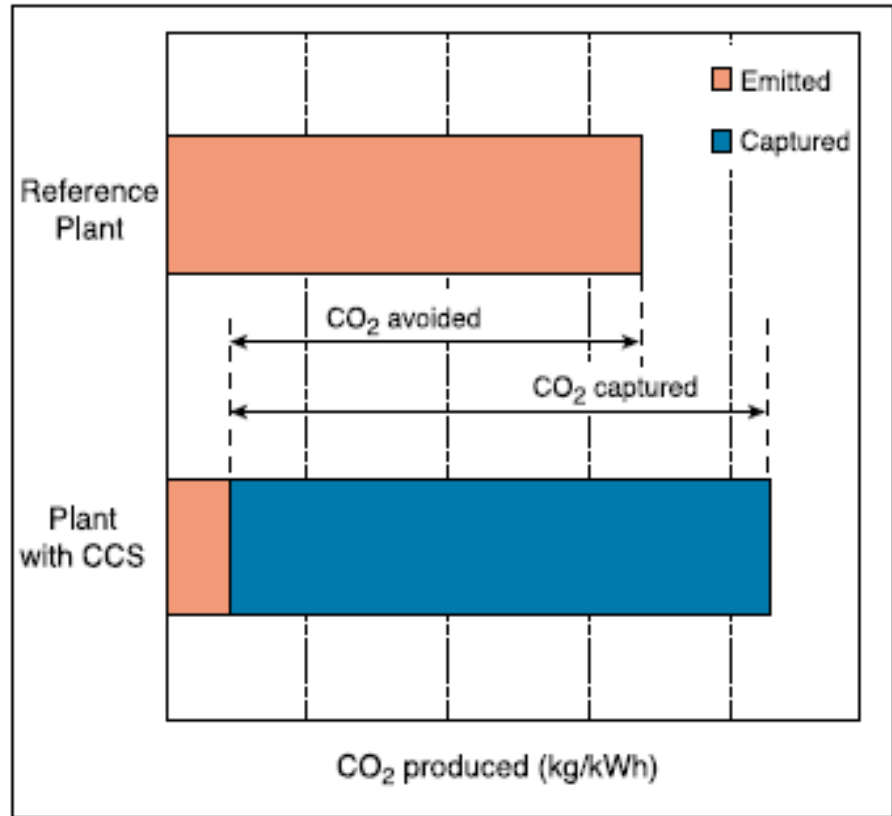

Source: IPCC Special Report, Figure 8.2.

\section{Author Contact Information}

Peter Folger

Specialist in Energy and Natural Resources Policy pfolger@crs.loc.gov, 7-1517

${ }^{78}$ IPCC Special Report, pp. 346-347. 